\title{
CHUVASH LOAN WORDS IN THE DIALECTS OF THE KRESHIN TATARS
}

\author{
PALAVRAS DE EMPRÉSTIMO CHUVASH NOS DIALETOS TARTARES DE \\ KRESHIN
}

\author{
PALABRAS DE PRÉSTAMO CHUVASH EN LOS DIALECTOS DE LOS TATARES DE \\ KRESHIN
}

\author{
Violetta Vitalyevna ANIFEROVA ${ }^{1}$ \\ Zoya Nikolaevna KIRILLOVA ${ }^{2}$ \\ Ercan ALKAYA ${ }^{3}$
}

\begin{abstract}
The article is intended to show the relations between Tatar and Chuvash and to examine Chuvash loan words in the dialect of Kreshin Tatar, which is a specific group of Tatar people. Tatars and Chuvash, who have lived as neighbors for a long time, not only have economic and daily relations, but also a mutual language influence, as a result of which mutual loans are exchanged between them. The paper also approaches the tight links between the two peoples and some language relations. Chuvash loans are present in the various aspects of daily life of the dialect of Melki Kreshins, for example, tundi kĭn (Monday), utlari kĭn (Tuesday), kekey (meat), kukşa (skinhead), kırsut (house fairy), cǐkres (twin), çaplī (good, beautiful), etc. to be compared with their Chuvash parallels, in terms of usage features. In addition, the dresses of girls and women of Melki Kreshins, which are accepted as Chuvash dresses, but whose names are not taken from Chuvash, such as takıya (women's headdress, decorated with bright stones and scales, fez), tastar (hijab made of white linen weave), tastar yawligi (tastar hijab), kaşpaw (round cap decorated with scales that used to be worn by women), etc. which will be examined on the basis of their equivalent in Tatar, Chuvash and other dialects.
\end{abstract}

KEYWORDS: Tatars. Chuvashes. Kreshin tatars. Dialects. Chuvash loans.

RESUMO: O artigo tem como objetivo mostrar as relações entre as línguas tartar e chuvash ao examinar as palavras emprestadas do chuvash no dialeto de Kreshin tartar, um grupo específico de tártaros. Tartaros e chuvaches, que viveram como vizinhos por muito tempo, não só têm relações econômicas e cotidianas, mas também têm influência linguística mútua, resultante de empréstimos mútuos. O artigo também abordará os estreitos vínculos entre os dois povos e algumas relações linguísticas. Serão observados empréstimos do chuvash presentes em várias áreas da vida diária do dialeto de Melki Kreshins, por exemplo, tundi kĭn (segunda-feira), utlari kìn (terça-feira), kekey (carne), kukşa (skinhead), kırsut (fada de casa),

1 Kazan Federal University (KPFU), Kazan - Russia. Master's student at the Department of General Linguistics and Turkic Studies, Institute of Philology and Intercultural Communication. ORCID: https://orcid.org/0000-00029203-4018. E-mail: zkirillova@yandex.ru

2 Kazan Federal University (KPFU), Kazan - Russia. Candidate of Philology, Associate Professor of the Department of General Linguistics and Turkology, Institute of Philology and Intercultural Communication. ORCID: https://orcid.org/0000-0002-2486-9320. E-mail: zkirillova@yandex.ru

3 Firat University, Elazı $\breve{g}$ - Turkey. Professor and Doctor of Philology. ORCID: https://orcid.org/0000-0002-96185614. E-mail: ealkaya16@gmail.com

Rev. EntreLínguas, Araraquara, v. 7, n. esp. 1, p. 22-30, fev. 2021.

E-ISSN: 2447-3529 
č̌kres (gêmeos), çaplı̆ (bom, bonito) etc. serão comparados com seus paralelos chuvash, em termos de características de uso. Além disso, os vestidos de meninas e mulheres de Melki Kreshins, que são aceitos como vestidos chuvash, mas cujos nomes não são retirados do chuvash, como taklya (adorno de cabeça feminino, decorado com pedras brilhantes e escamas, fez), tastar (hijab feito de tecido de linho branco), tastar yawligi (tastar hijab), kaşpaw (gorro redondo decorado com escamas, usado por mulheres no passado), etc. serão examinados com base em sua equivalência em tártaro, chuvash e outros dialetos.

PALAVRAS-CHAVE: Tártaros. Chuvashes. Tártaros kreshin. Dialetos. Empréstimos de chuvash.

RESUMEN: El artículo tiene la intención de mostrar las relaciones entre tártaros y chuvash y examinar las palabras prestadas de chuvash en el dialecto de kreshin tártaro, que es un grupo especial de gente tártara. no solo tienen relaciones económicas y diarias, sino que también tienen la influencia mutua de los idiomas, como resultado de lo cual los préstamos mutuos se transfieren entre sí. El documento también abordará los estrechos vínculos entre los dos pueblos y algunas relaciones lingüisticas. Chuvash préstamos que entran en las diversas áreas de la vida cotidiana en el dialecto de Melki Kreshins, por ejemplo, tundi kin (lunes), utlari kin (martes), kekey (carne), kukşa (cabeza rapada), kırsut (hada de la casa), cǐkres (gemelo), çapli (bueno, hermoso) etc. se compararán con sus paralelos de Chuvash, en términos de características de uso. Además, los vestidos de niñas y mujeres de Melki Kreshins, que se aceptan como vestidos de Chuvash, pero cuyos nombres no se toman de Chuvash, como Taklya (tocado de mujer, decorado con piedras brillantes y escamas, fez), tastar (hijab hecho de tejido de lino blanco), tastar yawligi (tastar hijab), kaşpaw (gorro redondo decorado con escamas y usado por mujeres en el pasado), etc., se examinarán sobre la base de su equivalencia en tártaro, chuvash y otros dialectos.

PALABRAS CLAVE: Tártaros. Chuvashes. Kreshin tártaros. Dialectos. Préstamos chuvasos.

\section{Introduction}

Chuvash loan words in the Melki or Tag Yag1 (mountain side) Kreshin Tatar Dialect, which is spoken around the Tatarstan border with Chuvashia, constitute the starting point of the article. The Melki group has a special place among Kreshin Tatars in Volga and Ural regions that constitute a religious group of Tatars. Many of them are christianized Tatars and the remaining of them are consisted of Tatarized Finno-Ugric peoples and Chuvash or the peoples that are influenced by them. There are various views on the origin of the Kreshin which strongly connect them to the Chuvash. These ideas and ethnic features of Melki Kreshins are included in the article. 


\section{Methods}

The following methods and techniques were used in the article: Description methods that includes observation, comparison and generalization; the dictionary definition method (interpretation), comparative-typological method, induction method which are used to acess the selected language features, etymological analysis and techniques such as analyzing the semantic parts of language units, etc. The subject of Chuvash loan words in the Kreshin Tatar Dialects has not been studied in other works, so the novelty of the study is emerged by itself.

\section{Results and discussion}

Languages features of Kreshin Tatar Dialects and their historical, incorporeal and religious culture, traditions and rituals have been studied in the works of F. S. Bayazitova's (BAYAZITOVA, 1997), "Istoriya i Kultura Tatar-Kryashen" (ISTORIYA; TATARKRYASHEN, 2017), E. Alkaya and Z. Kirilova's "Kreshin Tatar Türkçesi” (ALKAYA; KIRILLOVA, 2018). Some information can also be found in the R. G Exmetyanov's comparative study upon Tatar and Chuvash language (EXMETYANOV, 2015). and in the Etymological Dictionary of Tatar Language (AXMETYANOV, 1978). Generally, works that examine the different aspects of the relations between language and culture or language and history can provide a basis for research, as well (GULER; KIRILLOVA; SAHIN, 2018; YERBULATOVA; KIRILLOVA; SAHIN, 2019; GULER; KIRILLOVA; SAHIN, 2019; SIBGAEVA; SALAKHOVA; HUSEYNOVA, 2019; KIRILLOVA; KALGANOVA, 2018).

Generally, historical and geographical aspects do not match up with each other in the Turkic world. Chuvash is distant from Tatar Turkic in the terms of their historical situation. Nevertheless, geographically Chuvash and Tatars are the closest communities and have lived in the same countries for a 1000 years. Some linguists (such as Poppe) affirm that $80 \%$ of Chuvash vocabularies were loaned from Tatar Turkic. The Tatar etymologist Rikhat Ehmetyanov, who did much of his works on comparative study of Tatar and Chuvash, said that the finding is true. According to his studies, some words, word patterns and meaning of words which were forgotten in Tatar are preserved in Chuvash. This situation is natural and quite common (EXMETYANOV, 2015).

Chuvash loan words are mostly seen in the dialect of Tatars who have lived together side by side with Chuvash. The dialect of Melki (aka Taw Yag1) of the Kreshin Tatars, who live in the district of Kaybıç border with Chuvashia, is one of them. Based on the places they live including the language and dialect features, Kazan Ard1, Tüben, Kama Kreshin and Nogay 
Bekler are included in the Middle Kazan dialect; Çistay and Melki (Taw Yagı) Kreshins are included in the West (Misher) Dialect. Melki Kreshins have a special place among them. There are various theories on the place of the Melki among Tatar Dialects in terms of language and cultural features. Tatar dialectologist Flora Bayazitova describes this group as a special group and states that this group not only has West (Misher) dialects' features, but also Middle (Kazan) dialects' features; also the dialect group is under the influence of Chuvash Language. More specifically, the dialect group is close to the West (Misher) dialect in terms of its phonetic features, but in the same time has common features with Middle (Kazan) Dialect. In terms of its morphological features, it is similar to Middle dialect, especially Kasım, Nokrat and Perm Tatar dialects, with a common Turkic pattern, specific for Tatar and Chuvash. Its vocabulary has old layer words with Chuvash words as well. According to F. S. Beyazitova, although there are common aspects in language features and material culture with the Chuvash, Melki Kreshins must be considered as old Tatars. Probably, close ties were strengthened with neighboring Chuvash when Christianity was accepted by them (BAYAZITOVA, 1997, p. 21).

Damir İsxakov criticizes the Melki Kreshins' Misher origin. According to the results of his research, Chuvash language firstly had old Misher layer and this is explained with the entry of Misher elements into the ethnic structure of Chuvash by R. Axmetyanov [5: 86, 204]. Therefore, Misher influence on Melki Kreshin language came through the Chuvash component. Furthermore, they have live side by side with the Chuvash people. Traces of connection with Chuvash are observed in the northern group of Mishers as well. Secondly, pairing Tatar component in Melki Kreshins with latest Misher poses difficulties. On the contrary, it is possible to be linked to the Turkic root of Golden Horde (ISTORIYA; TATAR-KRYASHEN, 2017, p. 228).

Apart from this, the ethnic formation was completed in the border region with Chuvash until Chuvash peoples were christianized in the first half of the 18th century. Kayum Nasiyri states that the Muslims of that time (1526's) were among the Chuvash. Many Chuvash people became Muslim. Women were exchanged between these two peoples. It is believed that there were a lot of Muslim named Rus 150 years ago. In our time, there are still people named as Rus. For this reason, they listed people whose name were Rus as Kreshin in the years when old records were kept. The matter of the records of these people which were kept in 1727 has still not been resolved. In such cases, Muslims were named as "Tatars" and non-Muslims as "Chuvash". It was also possible to call Chuvash people who accepted the Islam as Muslim (ISTORIYA; TATAR-KRYASHEN, 2017, p. 228). 
At the end of the 19th century, Chuvash historian and ethnographer V.K. Magnistky wrote that Tatar-Chuvash girls (Melki-Tav Yag1 Kreshin girls) were married to native Chuvash. It is said that at the beginning of the 20th century, most of Melki (Tav Yag1) Kreshins' wives were Chuvash girls from neighboring villages. Mixed marriages show their effect in terms of ethnics and language. At the first half of the 18th century $60 \%$ of Tav Yag1 Kreshins were Chuvash and $40 \%$ of them were Tatars. Current classification should be accepted as conditional because of very intense relations between these two groups. However, these two groups were not as mixed with each other in the middle of the 20th century. At the beginning of this century, 4-5 thousand Chuvash were assimilated by Tatars to this group. Furthermore, the shaping of Tav Yag1 (Melki) Kreshins not only remained with assimilation, but also reminds the stage of arbitration process started from mid-centuries (ISTORIYA; TATAR-KRYASHEN, 2017, p. 229-230).

Generally, various ideas have been put forward about the formation of this group since past times. For example, in the 19th century, a group of writers (A. KOMISSAROV, A. PÇELOV ET. AL.) described Melki Kreshin as Tatarized Chuvash, while another group (A. RITTIX, N. ZOLOTNITSKIY, V. MAGNITSKIY, G. FILIPPOV ET. AL.) believes that the Tatar were influenced by the Chuvash. In an article released in1889, Mirolyubov wrote that both Tatar and Chuvash contributed to the formation of this group. In the 1920's, historian Nikolay Vorobyev put forward an original idea that Melki Kreshins were formed from a general Bulgar origin common to Tatars and Chuvash, which had taken place before the splitting of these two groups (ISTORIYA; TATAR-KRYASHEN, 2017, p. 225). However, Kreshin name started to be used at the beggining of the 20th century. Until this time, Chuvash name used to appear in the documents of this group. At the same time, some villagers were recorded as "Tatar of Kreshin" in the document of 18-19th century. Chuvash and Misher have a lot of common traits in material culture and language features.

As it is understood from the researches done in the 20th century and the beginning of 21 th century, the language features and material culture allow to reach a conclusion that Misher Tatar, Lower Chuvash (Anatri), Finno-Ugric people and Kipchak-Nogay of Volga area had an effect on shaping the group.

As is seen, this group has very complex ethnic roots and mutual views, which have been going on for several centuries. There are issues that have not been reconciled until today.

Chuvash loan words have an important place in the dialect of Melki Kreshin. These loan words are mainly about daily life. However, there are also words for expressing abstract ideas. 
Chuvash words are used for two days of the week. Tündi kĭn, in literary Tatar language düşembĭ (Monday), in Chuvash tüntikun. Utlari kĭn, in literary Tatar language şişembĭ (Tuesday), in Chuvash itlarikun.

Kekey: In Tatar (meat), in Chuvash Kakay, at the same time, mostly the word aş is used in the meaning of meat. Interestingly, the origin of "kakay" is shown as "gakay, gaxah (pig)" in Mongolian, in Çuvaş Třlı̆nĭn Etimologik Süzlĭgĭ. According to the Yegorov, firstly Chuvash used this word only for the pork and later started to use it for beef.

Kukşa: Skinhead, bald has the same writing in Chuvash. According to the Fedetov, the word "kuşka" is originating from the Turkic word "kakşa". For example, the word means "to dry, drying up and falling off" in Altai Turkic (used for overripe cereals). Kak means "dried, solid, dry" in Turkic dialects.

Çaplĭ: Yaxşı and matur (nice, good) are used instead of the word in literary Tatar language. Other variants of the words are muxtavlı̆, hiseplü, layı̌x in Chuvash. The word and its variants mean "celebrity, glories" in that language, at the same time, the word can also be translated as "famous, well-known, important, magnificent, rich and ornate".

Tĭmĭre: In Tatar, toman (fog, mist). In Chuvash, yankar, which is synonym of tĭtre, is used for fog and mist, as well. In addition, tĭtre reşeni means dull weather, fog of liquid and the rain falling slowly.

Aldır: The big wooden scoop used for making beer at home. In Chuvash, altăr; fistly means big scoop, shovel (Altăr śăltăr- Heptagon star), secondly means trough, bait, groove. According to the M. R. Fedetov, altăr is originated from alt- root in Turkic, but this word is only used in Bashkir Turkic among Turkic dialects. In Bashkir “alder" means big wooden bowl.

The clothing styles of women and girls of Melki Kreshins are very similar toChuvash's, but their names are not Chuvash. Such as takıya (women headdresses decorated with shiny stones and sequins, fez), tastar (headscarf made of white linen weaving), tostar cawlig1 (tastar hijab), kaşpaw (rounded cap decorated with scales, which women wore in the past), etc. As it is common with Chuvash, it is necessary to comment these words and their definitions.

Melki Kreshin girls wear sequined takıya during the feast days. The takıya is a headdress with a decorated upper part with variously colored silvery. Its lower side is decorated with small silver sequins. The takıya is made in a semicircular shape, $2-3 \mathrm{~cm}$ height of solid material such as wood or tin is placed as an edge on the top. Its lower part made with eared. In old times, takıya was present in all groups of Tatar people and it was known as the headdress of the girls in other Turkic tribes an in Finno-Ugric peoples. Chuvash peoples call takıya as tuxya "headdress of girls". In Bashkir, the word is in the form of tuxya. In the neighboring Finno- 
Ugric people such as Mari, Udmurt, Bisermens, which have lived together with Turkic tribes for a long time, headdress of girls have been called as takiya [1: 94]. In Danube Bulgars, the word means "beret" in the form of "takî". According to the materials of ethnographer N. İ. Vorobyev, the takıya is a common headdress that girls wear, which is high and hard. The takiya of the Melki Kreshin girls is very similar to Chuvash's tuxya. Chuavsh scholars V.G. Yegorov and M. R. Fedetov also registered many equivalent forms of the word "tuxya" in other languages and emphasize that this word is originated from Arabic.

While Melki Kreshin girls wear takıya, their women wear tastar (headscarf made of white linen weave), tastar cawlıgı (tastar hijab), kaşpaw (rounded cap decorated with scales, worn by women in old times). Tastar word is loan from Persian and means turban [4, II: 222]. It is a headdress woven at home in the form of towel just like ak cawlik. But it is longer (up to 2 meters) and its tips are decorated by weaving various colored ropes. Tambour embroidered fabric is placed under the headdress and white lace is put on its trim. A short towel tastar cawlig1 is attached to its top, so that Tastar stay firmly on the head. Its trims are decorated with weaving. Headdresses like tastar have been used by women of some Chuvash and Mishers groups. Generally, a towel shaped headdresses could be found in Finno-Ugric and in Slavic people in old times. According to the ethnographers, these type of headscarves were firstly unique to the Turkish women who lived in Central Asia. They spread quite early in the Middle Volga Region. Various variant of these have occurred everywhere for many years. Tastar is also known as a headdress in Bashkir, Bisermen, Udmurt et. al. In Chuvash, tastar is known as an old word, a similar headdressr is called as surpan or sorpan. The origin of surpan is considered as Persian (ser "head" and bend "wrapping, tying").

During the feast days, Melki women wore kaşpaw on their heads. There are variants of the words as kaşbaw or kaşmaw. It is considered as a Turkic word, formed by merging kaş "eyebrow" and baw "tie", since the head wear falls on the eyebrow. It is said that various phonetic variant of the word appear in various ways. For example, there are opinions that the "maw" in the word is originated from "female cap" in Chinese and the "paw" element in the word is originated from "pak - pag" "eyebrow (forehead) clothing" in Persian [4, I: 386]. Kaşpaw is sewn in the form of cut cone, small beads are lined up on the upside and the bigger ones at the bottom. This type of headdress is widely spread among Kazan Tatars. It is also present in Lembre "kaşpaw" and Temkinon "kaşbaw" which are groups of Tatar, in Bashkir "kaşmaw", in Chuvash "xuşpu" and in Bismen "kaşpu". It can be said that Kaşpaw has been a widely spread headscarf among Turkic tribes of Volga region for a long time (Guler, Kirillova, \& Sahin, 2018 .95). Xuşpu is considered an old word in Chuvash. V. G. Yegerov states that this 
word is the name of an old headdress decorated with silver stamps and beads by married women. On the other hand, M. R. Fedetov disagrees with Ashmarinand, he states that xuşpu narrows down from the back to the bottom of the knees and is decorated with beads and worn at weddings. The xuşpu word is seen in Chuvash dialects as xoşpu. There are five types of headdresses in terms of their spreading location, fabric and how they are made.

\section{Summary}

Chuvash loans have an important place in Melki Dialect of Kreshin Tatars. This dialect has a complex origin and contradictory views have been put forward by scientists to the identify them. The studying of language features and material culture allow the inference that Tatar, Chuvash, Finno-Ugric peoples and Kipchak-Nogay contributed to the formation of the group. Chuvash loans in Melki (Tav Yag1) Kreshin Dialect are generally economic and daily words. Nevertheless, words expressing abstract concepts are also observed.

The headdress used in Melki Kreshins show great similarity with the Chuvash. At the same time, it is also possible to consider them as old dresses - common the people of the Middle Volga and Ural region. The names of headdresses which were examined in the article are considered loan words from Persian "tastar" and Arabic "takıya" or has a Turkic origin "kaşpaw".

\section{Conclusions}

As observed, the Tatars and Chuvash, which are include in the Kipchak and Bulgar group of Turkic Tribes, have been neighbors for a long time and lived in a very close relationship. They have loaned language materials to each other. Chuvash words are numerous in Kreshin Melki, whose people live on the rayon bordering the Republic of Chuvashia. The dialect of the Melki Kreshins are considered differently by scientist in terms of their origins and language feature, common points with Chuvash are also observed in its material culture.

ACKNOWLEDGEMENTS: The work is performed according to the Russian Government Program of Competitive Growth of Kazan Federal University. 


\section{REFERENCES}

ALKAYA, E.; KIRILLOVA, Z. Kreşin tatar türkçesi:(dil, tarih, kültür). Kesit, 2018.

AXMETYANOV, R. G. Sravnitelnoye islledovaniye tatarskogo i chuvashskogo yazikov (fonetika i leksika). Moskva: Nauka, 1978.

BAYAZITOVA, F. S. Keräşennär. Tel üzençälekläre häm yola icatı. Kazan: Matbuğat yortı, 1997.

EXMETYANOV, R. G. Tatar teleneng etimologik süzlege. Kazan: Megarif - Vakıt, 2015. v. I-II, $543 \mathrm{p}$.

GULER, O.; KIRILLOVA, Z. N.; SAHIN, L. Lexical features of christian tatar subdialects. Amazonia Investiga, v. 7, n. 15, p. 185-189, 2018.

GULER, O.; KIRILLOVA, Z.; SAHIN, L. Language Features of Books for Christian Tatars and Karaman Turks. Revista Genero \& Direito, João Pessoa, v. 8, n. 7, p. 421-428, 2019. DOI: https://doi.org/10.22478/ufpb.2179-7137.2019v8n7.50046

ISTORIYA, I. TATAR-KRYASHEN, K. (XVI-XX vv.): Kollektivnaya Monografiya. Kazan, Institut Istorii im, 2017. 960 p.

KIRILLOVA, Z. N.; KALGANOVA, G. F. Continuous Education in the Tatar Language: History and the Present. The European Proceedings of Social \& Behavioural Sciences, v. 45 , p. 554-562, 2018.

SIBGAEVA, F. R.; SALAKHOVA, R. R.; HUSEYNOVA, M. N. Structural and wordformative features of verbs of behavior in the tatar language. Revista Genero \& Direito, v. 8, n. 7, p. 39-48, 2019.

YERBULATOVA, I. K.; KIRILLOVA, Z. N.; SAHIN, L. National and cultural realias of translations into tatar. Humanities \& Social Sciences Reviews, v. 7, n. 6, p. 984-987, 2019.

\section{How to reference this article}

ANIFEROVA, V. V.; KIRILLOVA, Z. N.; ALKAYA, E. Chuvash loan words in the dialects of the kreshin tatars. Rev. EntreLínguas, Araraquara, v. 7, n. esp. 1, p. 22-30, fev. 2021. eISSN: 2447-3529. DOI: https://doi.org/10.29051/el.v7iEsp1.14855

Submitted: $28 / 10 / 2020$

Required revisions: $19 / 12 / 2020$

Approved: $13 / 01 / 2021$

Published: 28/02/2021 